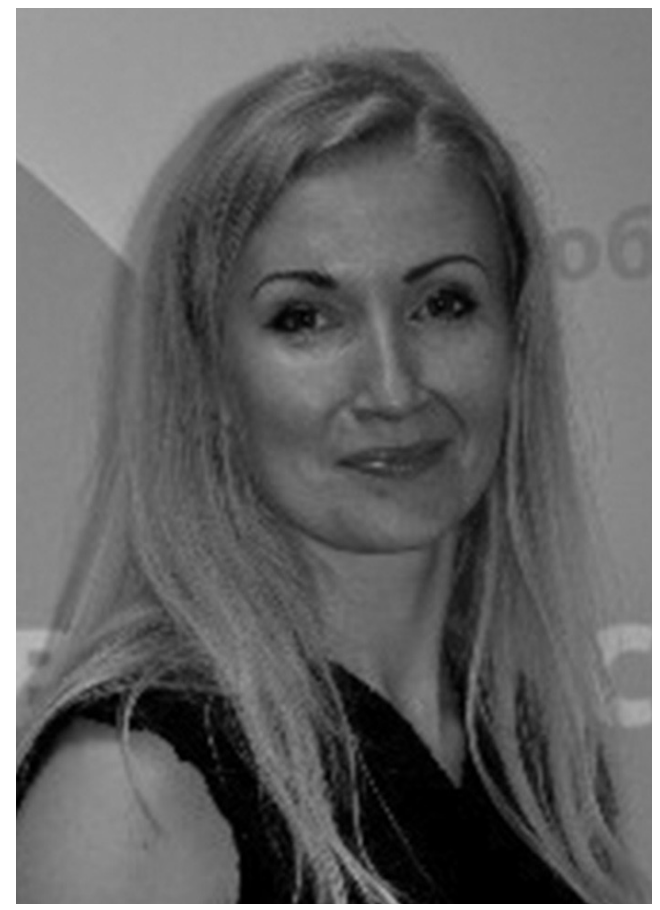

\title{
UDC 351.773
}

https://doi.org/10.32689/2617-22242020-4(24)-110-124

Дузь Оксана Миколаївна, аспірант кафедри соціальної та гуманітарної політики, Національна академія державного управління при Президентові України, 03057, м. Київ, вул. Антона Цедіка, 20, тел.: (044) 48121 55, e-mail:duzoksana2@gmail.com, https:// orcid.org/0001-0003-5773-3166

\section{Дузь Оксана Николаевна}

аспирант кафедры социальной и гуманитарной политики, Нащиональная академия государственного управления при Президенте Украины, 03057, г. Киев, ул. Антона Цедика, 20, тел.: (044) 4812155 , e-mail: duzoksana2@gmail.com, https:// orcid.org/0001-0003-5773-3166

Duz Oksana Nikolaezna,

PhD, Department of Social and Humanitarian Policy, National Academy of Public Administration under the President of Ukraine, 03057, Kyiv, Str. Anton Tsedik, 20, tel.: (044) 481 21 55, e-mail: duzoksana2@gmail.com, https://orcid.org/0001-0003-5773-3166

\section{ЕТАПИ СТАНОВЛЕННЯ МЕХАНІЗМІВ ДЕРЖАВНОГО РЕГУЛЮВАННЯ ТРАНСФОРМАЦІЇ МЕДИЧНОЇ ДОПОМОГИ ХВОРИМ ЗІ ЗЛОЯКІСНИМИ НОВОУТВОРЕННЯМИ В УКРАÏHI}

Анотація. Розглянуто етапи і механізми державного регулювання реформування медичної допомоги хворим зі злоякісними захворюваннями в Україні, проаналізовано програми дій в галузі, нормативно-правове забезпечення, суб'єкти управління і відповідальні особи; об’єкти реформування, узгодження запроваджуваних змін з іншими складовими суспільної системи. Про недоліки системи охорони здоров'я України свідчить зростання показників смертності від злоякісних новоутворень, а також неефективний захист населення від ризику катастрофічних витрат у випадку онкологічного захворювання. Основне завдання - зниження рівня захворюваності на злоякісні новоутворення в Україні шляхом профілактики, раннього виявлення, 
якісного лікування хворих зі злоякісними новоутвореннями, покращення якості життя пацієнтів та зниження рівня смертності.

Досягнення визначених завдань передбачає кілька важливих напрямів роботи: забезпечення первинної профілактики онкологічних захворювань, вплив факторів ризику та покращення поінформованості населення із залученням до активних дій; сприяння ранньому виявленню злоякісних новоутворень; забезпечення рівноправного і постійного доступу до спроможної мережі закладів охорони здоров’я для діагностики і лікування дорослих хворих і дітей зі злоякісними новоутвореннями; забезпечення реабілітації, догляду і паліативної допомоги хворим зі злоякісними новутвореннями i підтримка доглядальників на всіх рівнях; покращення інформаційних систем реєстрації злоякісних новоутворень та спостереження за хворими зі злоякісними новоутвореннями для відстеження динаміки результатів і заходів контролю злоякісних новоутворнеь; підвищення рівня професійної освіти лікарів, середнього медичного персоналу, підготовка управлінських кадрів; проведення клінічних досліджень II та III фази з наступним використанням результатів для контролю злоякісних новоутворень.

Вирішення цього питання знаходиться на межі соціального, організаційного та економічного аспектів суспільного життя. I вочевидь нагальним є продовження реформування медичної допомоги хворим зі злоякісними новоутвореннями в Україні із застосуванням майбутніх інноваційніх підходів, які мають забезпечити конституційні гарантії необмеженого доступу до медичної допомоги хворим зі злоякісними новоутвореннями.

Ключові слова: реформування, медична допомога, злоякісне новоутворення, онкологічна служба, державна політика, інноваційці підходи.

\section{ЭТАПЫ СТАНОВЛЕНИЯ МЕХАНИЗМОВ ГОСУДАРСТВЕННОГО РЕГУЛИРОВАНИЯ ТРАНСФОРМАЦИИ МЕДИЦИНСКОЙ ПОМОЩИ БОЛЬНЫМ СО ЗЛОКАЧЕСТВЕННЫМИ НОВООБРАЗОВАНИЯМИ В УКРАИНЕ}

Аннотация. Рассмотрены этапы и механизмы государственного регулирования реформирования медицинской помощи больным со злокачественными заболеваниями в Украине, проанализированы программы действий в отрасли, нормативно-правовое обеспечение, субъекты управления и ответственные лица; объекты реформирования, согласование внедряемых изменеий с другими составляющими общественной системы. О недостатках системы здравоохранения Украины свидетельствуют повышение показателей смертности от злокачественных новообразований, а также неэффективная защита населения от риска катастрофических расходов в случае онкологического заболевания. Основное задание - снижение уровня заболеваемости злокачественными новообразованиями в Украине путем профилактики, раннего определения, качественного лечения пациентов со злокачественными новообразованиями, улучшение качества жизни пациентов и снижение уровня смертности. 
Достижение определенных заданий предусматривает несколько важных направлений работы: обеспечение первичной профилактики злокачественных нововобразований, влияние факторов риска и улучшение информированости населения с вовлечением к активным действиям; содействие раннему выявлению злокачественных новообразований; обеспечение равноправного и постоянного доступа к обеспеченной сети учреждений охраны здоровья для диагностики и лечения взрослых и детей, больных злокачественными новообразованиями; обеспечение реабилитации, ухода и паллиативной помощи больным со злокачественными новообразованиями и поддежка сиделок на всех уровнях; улучшение информационных систем регистрации злокачественных новообразований и наблюдение за больными со злокачественными новообразованиями для отслеживания динамики результатов и мероприятий контроля злокачественных новообразований; повышение уровня профессионального образования врачей, среднего медицинского персонала, подготовка управленческих кадров; проведение клинических исследований II и III фазы с последующим использованием результатов для контроля злокачественных новообразований.

Решение данного вопроса находится на стыке социального, организационного и экономического аспектов общественной жизни.Очевидно, актуальным есть продолжение реформирования медицинской помощи больным со злокачественными новообразованиями в Украине с использованием будущих инновационных подходов, которые имеют необходимость обеспечить конституционные гарантии неограниченого доступа к медицинской помощи больных со злокачественными новообразованиями.

Ключевые слова: реформирование, медицинская помощь, злокачественное новообазование, онкологическая служба, государственная политика, инновационные подходы

\title{
STAGES OF FORMATION OF MECHANISMS OF STATE REGULATION OF TRANSFORMATION OF MEDICAL CARE FOR PATIENTS WITH MALIGNANT NEOPLASMS IN UKRAINE
}

\begin{abstract}
The article discusses the stages and mechanisms of state regulation of reforming medical care for patients with malignant diseases in Ukraine, analyzes the action programs in the field of regulatory support, management entities and responsible persons; objects of reform, coordination of the introduced changes with other components of the social system. The shortcomings of the health care system in Ukraine are evidenced by an increase in mortality rates from malignant neoplasms, as well as ineffective protection of the population from the risk of catastrophic costs in the event of cancer. The main task is to reduce the incidence of malignant neoplasms in Ukraine through prevention, early detection, high-quality treatment of patients with malignant neoplasms, improving the quality of life of patients and reducing mortality. Achievement of certain tasks provides for several important areas of work: provision of primary prevention of oncological diseases,
\end{abstract}


the influence of risk factors and improving public awareness with the involvement of active actions; promoting early detection of malignant neoplasms; ensuring equal and permanent access to a capable network of health care institutions for the diagnosis and treatment of adult patients and children with malignant neoplasms; provision of rehabilitation, care and palliative care for patients with malignant neoplasms and support of nurses at all levels; improvement of information systems for registering malignant neoplasms and monitoring patients with malignant neoplasms to track the dynamics of results and measures to control malignant neoplasms; raising the level of professional education of doctors, nurses, training of management personnel; conducting phase II and III clinical trials with the subsequent use of the results for the control of malignant neoplasms.

The solution to this issue is on the verge of the social, organizational and economic aspects of public life. And it is obviously relevant - there is a continuation of the reform of medical care for patients with malignant neoplasms in Ukraine with the use of future innovative approaches, which should provide constitutional guarantees of unlimited access to medical care for patients with malignant neoplasms.

Keywords: reforming, medical care, malignant neoplasm, oncological service, state policy, innovative approaches.

Постановка проблеми. Злоякісні новоутворення разом із хворобами системи кровообігу є визначальними у здоров'ї населення України, беручи до уваги те, що вони зумовлюють $12 \%$ випадків у структурі смертності та $26 \%$ у структурі інвалідизації населення. На сьогодні кількість хворих, що страждають на злоякісні новоутворення і які перебувають на обліку в онкологічних відділеннях по всій Україні, становить понад 850 тис. осіб. Щорічно реєструється від 160 до 180 тис. осіб хворих на рак, від нього помирає майже 100 тис. осіб.

Через запізнілу діагностику онкологічних захворювань залишається значною кількість хворих, які помирають протягом року після встановлення діагнозу (38-40\%). Особливу стурбованість викликає той факт, що значну частину померлих ста- новлять громадяни працездатного віку. Високий рівень захворюваності на злоякісні новоутворення населення України та висока частка даної патології у структурі смертності населення вимагає нових підходів до розробки способів та методів профілактики, раннього виявлення та ефективного лікування. При цьому повинні враховуватися всі детермінанти, що сприяють виникненню злоякісних новоутворень та способи їх усунення. В Україні рак визначено як соціально небезпечне захворювання, тому забезпечується реєстрація кожного випадку злоякісного новоутворення на державному рівні.

Аналіз останніх досліджень і публікацій. Питання розвитку та реформування сфери охорони здоров'я та іï законодавчого забезпечення 
вже стало предметом розгляду багатьох дослідників. Серед них слід назвати Т. Авраменко, М. Білинську, Н. Васюк, 3. Гладуна, Л. Жаліло, В. Князевича, Н. Кризину, О. Мартинюк, В. Москаленка, В. Пашкова, Я. Радиша, І. Рожкову, І. Солоненка, Н. Янюк, Н. Ярош та інших науковців. Багато робіт присвячено дослідженням питань державного управління та реалізації державної політики у сфері профілактики і боротьби з онкологічними захворюваннями. Питання забезпечення прав онкохворих в Україні розглядалося 3 позиції надання таким особам паліативної чи хоспісної допомоги (А. Царенко, Ю. Губський, О. Скорина), ідеї права на життя без болю (В. Галунько та B. Наружнов, F. Brennan, S. H. Johnson).

Мета наукового дослідження показати нагальність подальшого реформування медичної допомоги хворим зі злоякісними новоутвореннями в Україні, окресливши існуючі стратегічні підходи в наданні медичної допомоги хворим зі злоякісними новоутвореннями, дослідивши етапи становлення механізмів державного регулювання трансформації медичної допомоги, розглянути перспективу майбутніх інноваційніх підходів у боротьбі зі злоякісними новоутвореннями в Україні.

Виклад основного матеріалу. Основним нормативним актом регулювання діяльності онкологічної служби та надання онкологічної допомоги населенню України після 1991 року був наказ МОЗ “Про заходи подальшого покращання i розвитку онкологічної допомоги населенню” (від 30.12.1992 № 208) [1].
Відповідно до наказу для покращення якості лікування заборонено планове лікування онкологічних хворих у загальнолікувальній мережі та обов'язковим $є$ залучення до лікування онкологічного хворого трьох спеціалістів - хірурга, хімотерапевта та променевого терапевта. Крім того, наказом визначено функціонування онкологічної служби взагалі та затверджено наступні положення про онкологічний диспансер, головного онколога, організаційно-методичний кабінет онкологічного диспансеру, онкологічний кабінет поліклініки, дитячий онкологічний кабінет, жіночий оглядовий кабінет лікувально-профілактичного закладу, чоловічий оглядовий кабінет лікувально-профілактичного закладу, централізовану цитологічну лабораторію лікувально-профілактичного закладу, протиракову експертну комісію, відділення автоматизованої системи управління обласного (міського) онкологічного диспансеру, онкохіміотерапевтичне відділення онкологічного диспансеру, кабінет амбулаторної хіміотерапії хворих онкологічного диспансеру.

Нова редакція наказу МО3 України "Про систему онкологічної допомоги населенню України” [2] була затверджена 01.10.2013 № 845, наказ набув чинності 18.02.2014 і є чинним на теперішній час. Наказом передбачено удосконалення державної системи протиракової боротьби, поліпшення стану діагностики, лікування та медико-соціальна реабілітація онкологічних хворих, що сприятиме зменшенню смертності від онкологічних захворювань, летальності онкологічних хворих праце- 
здатного віку, зниження показників занедбаності, збільшення виживаності онкологічних хворих, а також зменшення ступеня інвалідізації. Цей наказ дає змогу забезпечити удосконалення та подальший розвиток сучасної, економічно доцільної та ефективної системи організації спеціалізованої допомоги онкологічним хворим, залежно від потреб населення та особливостей регіону, що дозволить забезпечити максимально можливу та гідну якість життя пацієнтам 3 онкологічними захворюваннями і збільшить тривалість життя хворим на рак, зменшить летальність хворих працездатного віку, що має велике соціальне, економічне та морально-етичне значення для усього суспільства. Наказ затверджує структуру та функції суб'єктів онкологічної служби, а саме: положення про головну установу 3 онкології, Національний канцер-реєстр України, онкологічний заклад (диспансер, центр, лікарня), інформаційно-аналітичний відділ онкологічного закладу, про денний стаціонар онкологічного диспансеру, онкохіміотерапевтичне відділення онкологічного диспансеру, кабінет для амбулаторної хіміотерапії хворих онкологічного диспансеру, онкологічний кабінет лікувально-профілактичного закладу, жіночий оглядовий кабінет лікувально-профілактичного закладу, кабінет патології шийки матки лікувально-профілактичного закладу, мамологічний кабінет лікувально-профілактичного закладу, чоловічий оглядовий кабінет лікувально-профілактичного закладу, централізовану цитологічну лабораторію, протиракову експерт- ну комісію, міжрегіональний онкологічний центр.

Наказом МОЗ України “Про створення Національного канцер-реєстру України” від 22.01.1996 р. № 10 в державі здійснюються заходи, спрямовані на забезпечення систематичного контролю за повнотою одержання та вірогідністю інформації про випадки захворюваності на рак. В Україні функціонує Національний канцер-реєстр України, де накопичується вся інформація про стан протиракової боротьби у державi, яка є джерелом для оперативного керівництва онкологічною службою та визначення шляхів ㄲi розвитку й удосконалення. Канцер-реєстр є автоматизованою системою збору, накопичення, збереження та обробки персоніфікованої інформації про онкологічних хворих. Адже вірогідна інформація про рівень захворюваності, смертності і поширеності злоякісних новоутворень, стан діагностики, лікування та реабілітації раку, а також забезпечення якості життя хворим зі злоякісними новоутвореннями та хворим у термінальній стадії - є основою для ефективного державного управління у сфері протиракової боротьби [3].

Темп приросту поширеності онкопатології у них за період 20052015 рр. становить 16,5 \%. Аналізуючи захворюваність населення України, встановлено, що частота захворюваності на онкологічну патологію за останні 10 років зросла від 333,7 на 100 тис. населення до 345,9 на 100 тис. населення. Темп зростання онкологічної патології в Україні у період 2005-2015 рр. становить 3,7 \%. Показник захворюваності на 
онкопатологію серед чоловіків у розрахунку на 100 тис. осіб у 2005 р. становив 354,6, а в 2015p. - 356,8. Темп приросту склав 0,6 \%. Серед жіночого населення аналогічний показник захворюваності становив у 2005 р. 315,8 на 100 тис. осіб, а в 2015 р. 336,5. Темп приросту захворюваності за період 2005-2015 рр. серед жіночого населення склав 6,6 \% [3].

Оцінка стану надання онкологічної допомоги населенню показала, що при зростанні рівня виявлення хворих зі злоякісними новоутвореннями на ранніх стадіях до 53,1\% та збільшенні охоплення спеціальним лікуванням до 68,7\%, питома вага хворих, що не прожили 1 року 3 моменту встановлення діагнозу, залишилася високою - 31,4\%, тобто впродовж першого року помер кожний третій хворий. Ці дані вказують на необхідність удосконалення медичної допомоги населенню України, що страждає на злоякісні новоутворення.

3 метою підвищення ефективності загальнодержавних заходів з профілактики (первинної, вторинної, третинної), раннього виявлення та лікування злоякісних новоутворень, зниження смертності, зменшення кількості випадків унаслідок захворювання на злоякісні новоутворення, створення умов для проживання та поліпшення якості життя хворих, що страждають на злоякісні новоутворення, Постановою Кабінету Міністрів України була затверджена Програма “Онкологія” на 20022006 рр. від 29.03.2002 р. № 392, а 24 липня 2006 р. створено Проект Державної програми “Боротьба з онкологічними захворюваннями на 2007 -
2016 рр.” Головною метою ухваленої у 2010 р. Парламентом України Загальнодержавної програми боротьби з онкологічними захворюваннями на період до 2016 р. було підвищення ефективності державних заходів щодо покращення якості та доступності допомоги хворим зі злоякісними захворюваннями, впровадження державних гарантій медичної допомоги, удосконалення умов для подовження життя онкологічних хворих та поліпшення його якості. Реалізація цієї стратегіï, за прогнозами онкологів, мала б забезпечити зниження смертності від онкопатології на 8-10 \% вже до 2016 р. За даними галузевої статистики у 2006 р. майже 35 \% вперше зареєстрованих злоякісних новоутворень виявлялось у третій і четвертій стадії онкологічного захворювання, коли шанси на ефективне спеціалізоване лікування (комбіноване та комплексне) та зцілення були малоймовірними, в результаті чого майже кожний третій хворий на злоякісне захворювання у занедбаній стадії протягом року встановлення діагнозу помирав. Незважаючи на покращення якості надання спеціалізованої онкологічної допомоги населенню нашої держави завдяки державним заходам, очікуваних кардинальних змін у профілактиці і ранній діагностиці та відповідно до ефективності спеціалізованого лікування хворих на злоякісні захворювання не відбулось [4].

Основні проблеми та недоліки Загальнодержавної Програми боротьби з онкологічними захворюваннями на період до 2016 р., затвердженої Законом України від 23.12.2009 р. № 1794-VI(далі - Програма), згідно 
3 думками експертів, наполягають в наступному: 1) програма передбачала утворення міжрегіональних онкологічних центрів, референтних лабораторій морфологічної, цитогенетичної та молекулярної діагностики злоякісних новоутворень за відсутності нормативно-правової документації; 2) було закладено нереальний для виконання обсяг завдань та заходів, які охоплюють усі складові організації протиракової боротьби, порівняно з реальною можливістю бюджетного фінансування; 3) не було визначено чіткі кількісні та якісні критерії оцінки виконання Програми: їх відсутність унеможливила проведення об'єктивного моніторингу та контролю за використанням бюджетних коштів; 4) при формуванні Програми не було проаналізовано потреби і вигоди регіонів; 5) Програма за період 2009-2016 рр. фінасувалася лише частково, здебільшого на закупівлю засобів для хіміотерапї та препаратів супроводу, за даними, оприлюдненими у період 2010-2015 рр. відповідно до фінансування Програми (загальний орієнтований обсяг визначено у розмірі 3756115700 грн), за рахунок коштів державного бюджету - 3238663400 грн) одержано лише 56977000 грн, тобто, 15,2 \% від загального запланованого державою і 17,6 \% від безпосередньо обіцяного [5].

Але вже ж таки були і позитивні зрушення: завдяки прийнятій Кабінетом Міністрів України Державній програмі “Онкологія" на 2002-2006 pр., Проекту Державної програми "Боротьба з онкологічними захворюваннями на 2007-2016 роки”, Указу Президента України
“Про невідкладні заходи щодо реформування системи охорони здоров’я населення" від 6.12.2005 р. почали розвиватися профілактичні технології (скринінгові програми), нові сучасні підходи до ранньої діагностики та спеціалізованого лікування в клінічній онкології, які прийняті в усьому світі. Пріоритетними в онкологічній службі України стали питання профілактики (первинної, вторинної, третинної) і ранньої діагностики та лікування злоякісних новоутворень. Рішення цих найважливіших питань неможливе без проведення фундаментальних медико-демографічних досліджень злоякісних новоутворень.

У Міжгалузевій комплексній програмі “Здоров’я нації” на 20022011 рр. означеній проблемі присвячено окремий розділ “Боротьба з раком”, пункти якого включають розробку регіональних систем заходів щодо зменшення канцерогенного впливу на людину, профілактики онкологічних захворювань на всіх рівнях, покращення оснащення діагностичних і лікувальних підрозділів для надання медичної допомоги онкологічним хворим з метою підвищення ii якості та своєчасності [6].

Результатом багаторічних фундаментальних і прикладних наукових досліджень стала розробка заходів первинної і вторинної профілактики злоякісних новоутворень. Зокрема, первинна профілактика раку полягає у створенні сприятливих умов життя, завдяки яким не реалізуються генетичні ризики виникнення захворювання. Передусім йдеться про відмову від паління, надмірного вживання алкоголю, боротьбу із зай- 
вою вагою, гіподинамією і запобігання інфекційним захворюванням, що передаються статевим шляхом. Вторинна профілактика - це профілактичний огляд і своєчасне обстеження, своєчасне лікування передракових станів та раннє лікування раку. Для практичної охорони здоров’я у плані реалізації основною проблемою залишається вторинна профілактика і раннє виявлення раку, тобто система заходів, спрямованих на виявлення хронічних передпухлинних і пухлинних захворювань у початкових стадіях.

Розробка та впровадження в практику потребують скринінгові програми, інструментально-лабораторні методи дослідження груп високого ризику виникнення захворювань та груп з передпухлинними патологіями, ефективність яких доведена економічно.

Беричи до уваги, що у 2006 р. майже 35 \% уперше зареєстрованих злоякісних новоутворень виявлялась у третій і четвертій стадії онкологічного захворювання, то важливість надання паліативної допомоги була незаперечною. У період незалежності нашої держави розпочато побудову системи паліативної та хоспісної допомоги, але щоб краще усвідомити цей процес стисло проаналізуємо важливі віхи становлення, розвитку цієї допомоги в Україні. Перші установи хоспісного типу в Україні було відкрито (за сприяння міжнародних організацій): у Львові (1996 р.), Івано-Франківську (1997 р.), Коростені (1998р.), які є на даний час провідними установами, що надають паліативну і хоспісну допомогу стаціонарно та амбулаторно. В 1999 р. створено Асоціацію малоінвазійної та паліативної терапії, якою було розроблено Маніфест хоспісного руху в Україні. В 2001 р. Всеукраїнською благодійною організацією "Рада захисту прав і безпеки пацієнтів”, яку було засновано за підтримки Міжнародного фонду “Відродження”, вперше в нашій державі було привернуто увагу громадськості до нагальних питань забезпечення прав інкурабельних пацієнтів. Так, у затвердженій Постановою Кабінету Міністрів України Міжгалузевій комплексній програмі “Здоров’я націï” на 2002-2011 рр. від 10.01.2002 р. № 14 було передбачено створення мереж хоспісів для симптоматичного лікування онкологічних хворих у термінальній стадії, розширення мережі денних стаціонарів і вдома, закладів (відділень) медико-соціальної допомоги та хоспісів. У 2006 р. утворено Міжвідомчу робочу групу 3 питання удосконалення правової бази паліативної допомоги, а в 2007 р. Всеукраїнську Асоціацію паліативної допомоги. В 2008 р. відповідно до Наказу МОЗ України від 17.04.2008 р. № 210 було створено Координаційну раду з паліативної та хоспісної допомоги при МОЗ України, якою розроблено проект концепції Державної цільової програми розвитку паліативної та хоспісної допомоги в Україні на 2010-2014 роки [7]. У 2008 р. Наказом МОЗ України від 24.07.2008 р. № 159-0 було створено Інститут паліативної та хоспісної медицини базової науково-методичної та клінічної установи MO3 України з питань надання паліативної та хоспісної допомоги. Також створено: кафедру паліативної 
та хоспісної медицини у Національній медичній академії післядипломної освіти ім. П. Л. Шупика (2009р.), в якій здійснюють фахову підготовку лікарів і медичних сестер цього напряму; Всеукраїнську громадську організацію. В Україні до сьогодні не сформована державна політика розвитку системи паліативної та хоспісної допомоги. Хоча протягом досліджуваного періоду в системі паліативної і хоспісної допомоги досягнуто певних зрушень та успіхів, але ініціативи, пріоритети політики щодо розвитку цієї системи, їх лобіювання в політичних колах формуються і здійснюються, як правило, “знизу”. Нерідко зусилля, намагання ініціативних груп у складі прогресивних лікарів, науковців, громадських організацій вирішити на державному рівні нагальні питання в цій системі наштовхуються на байдужість з боку політиків, політичних партій та нівелюються ними. Підтвердженням цього є неприйняття урядом України Проекту Концепції Державної цільової програми розвитку паліативної та хоспісної допомоги на 2010-2014 pp. [7], який у 2008 р. розроблено "Українською лігою розвитку паліативної та хоспісної допомоги”, представниками інших громадських організацій, фахівцями, науковцями в цій системі, та було подано МО3 України на розгляд до КМУ. Українські політики, урядовці, представники виконавчої влади залишаються недостатньо поінформованими про масштабність, сучасні тенденції до поглиблення проблем паліативної та хоспісної допомоги, поверхнево розуміючи ii соціально-економічне та гуманітарне зна- чення [8]. Організацію “Українська Ліга сприяння розвитку паліативної та хоспісної допомоги” (2010р.), яка має свої організації майже у всіх регіонах України. В організації надання паліативної та хоспісної допомоги є серйозні проблеми, які значною мірою детерміновані недоліками в організаційному та інших механізмах державного управління цією сферою.

Масштаби охоплення цими проблемами є загальнодержавними, що доводять необхідність у невідкладному їх розгляді та вирішенні на рівні вищих, центральних органів державної влади, які мають забезпечити належне регулювання суспільних відносин у цій системі, реалізацію інкурабельними пацієнтами конституційно гарантованого їм права на медичну допомогу та відповідну підтримку. Невідкладною є потреба в розробці та впровадженні такого організаційного механізму державного управління паліативною та хоспісної допомогою, який дав би змогу не тільки ефективно розв’язати вказані проблеми, а й постійно забезпечувати надання такої допомоги і дорослим і дітям зі злоякісними новоутвореннями в необхідних обсягах та на належному рівні якості.

Таким чином, рівень медичної допомоги населенню України, що страждає на злоякісні новоутворення, все ще не відповідає реальним потребам і сучасним вимогам, а забезпечення ефективної та прийнятної 3 економічного погляду медичної допомоги хворим зі злоякісними захорюваннями має залишатися одним із пріоритетних завдань охорони здоров’я населення. Для вирішення цьо- 
го завдання, крім клінічної частини, потрібно ще кілька складових, які знаходяться на межі соціального, організаційного, економічного аспектів суспільного життя [7, 9]. Існує значна потреба в організації і проведенні реабілітаційних заходів для працездатних пацієнтів з первинною інвалідизацією внаслідок злоякісних новоутворень. За статистичними даними Українського державного науково-дослідного інституту медико-соціальних проблем інвалідності (на основі річних звітів Медико-соціальної експертної комісії, починаючи з 2001 р.), частка працездатних пацієнтів серед осіб з інвалідністю, зумовленою злоякісними новоутвореннями, у різних регіонах України варіює в межах 50-90 \%, в Україні загалом - 65-75 \%. Типові програми і стандарти індивідуальної реабілітації повнолітніх інвалідів зі злоякісними захворюваннями у нашій країні не розроблені. У Міністерстві охорони здоров'я відсутня система реабілітації онкологічних хворих, а у Міністерстві соціальної політики немає нормативних документів щодо проведення такої реабілітації. Украй мало програм реабілітації інвалідів зі злоякісними новоутвореннями розробляються і реалізуються локально (у межах окремих об'єднань і закладів реабілітації (найчастіше розрахункових), окремих регіональних програм). Тому актуальними є дослідження та практичні кроки, спрямовані на забезпечення реабілітації хворих/інвалідів онкологічного профілю не тільки в процесі стандартного лікування з приводу злоякісних новоутворень, а й більш тривалого їх відновлення. Повноцінна реабі- літація $є$ важливою складовою як для профілактики рецидивів злоякісних новоутворень і ускладнень протипухлинного лікування, так i підвищення якості життя пацієнтів, поновлення їх інтеграції в суспільне життя, що матиме не тільки суто медичний, а й позитивний соціальний та економічний ефекти [10; 11].

Під час XIII з'ізду онкологів та радіологів України, який відбувся 26-28 травня 2016 р. у м. Києві за підтримки Міністерства охорони здоров’я(МО3) України, Національної академії наук (НАН) України, Національної академії медичних наук (НАМН) України та Національного інституту раку МОЗ України, були розглянуті напрями розвитку онкології шляхом створення загальної концепції розвитку національної системи онкологічної допомоги у послідовності: принципи - логіка розвитку - структура. Гаслом концепції визначили “Людину у центрі уваги”. Відповідно, були сформовані стратегічні цілі: стратегічна ціль № 1 - стабільно високий рівень якості медичної допомоги; стратегічна ціль № 2 - формування передової науково-інноваційної системи; стратегічна ціль № 3 - створення і розвиток нової освітньої системи; стратегічна ціль № 4 - створення високоефективної системи трансферту передових технологій. Фахівці-експерти галузі наголошують на необхідності залучення інвестицій для нормального розвитку галузі й окремо торкнулася ключових принципів бюджетної політики, зокрема: 1) розвитку багатоканального фінансування, максимального збільшення його за рахунок позабюджетних 
джерел (зокрема, важливим ресурсом позабюджетного фінансування, що сприяє залученню інвесторів до експертного супроводу діяльності та проектів, підготовки управлінських кадрів тощо, є державно-приватне партнерство; 2) участі у багатоцентрових рандомізованих дослідженнях II i III фаз із вивчення ефективності лікраських засобів у лікуванні пацієнтів з онкологічними захворюваннями (переваги отримують пацієнти, лікарі, науковці); 3) залучення інвестицій від міжнародних (приватних та урядових) організацій для фінансування наукових досліджень (“Горизонт 2020”. План дій “Україна-Свропейський Союз”, 7-ма Рамкова програма СС та ін.) [12].

Перетворення i реформи, що здійснюються в Україні, нерозривно пов’язані з пошуком принципово нових методів організації та управління медичною сферою. Це потребує адекватних змін у структурі планування матеріально-технічного забезпечення виробництва медичних послуг i, відповідно, зумовлює необхідність удосконалення системи облікової інформації, потрібної для прийняття управлінських рішень. Ефективність господарської діяльності медичних закладів значною мірою залежить від оцінки та раціонального використання виробничих запасів.

Виходячи 3 потреб сьогодення, нагальною необхідністю є аналіз основних показників діяльності та ii. планування окремих лікувальних закладів. Крайня потреба такого аналізу диктується вимогами функціонування спеціалізованої медичної установи в умовах великого міста. Щоб спланувати дослідження лі- кувального закладу, обраного для аналізу відповідно до пріоритету, визначають мету аналізу; користувачів результатів дослідження; перспективу дослідження (суспільство, уряд, лікувально-профілактичний заклад, пацієнт); часові параметри розрахунку (тривалість перебування пацієнта в стаціонарі, термін до повного одужання, тривалість життя пацієнта); групу пацієнтів (вік, стать, діагноз, супутні захворювання і т. ін.); вибір технології та лікарських засобів у порівнянні (краща альтернатива, стандартна технологія і т. ін.). При виборі параметри повинні бути взаємопов'язаними. Якщо результати фармакоекономічного аналізу є необхідними для складання формуляра індивідуальної лікарні, тоді в обчисленнях буде враховано лише витрати, пов'язані з перебуванням пацієнта у стаціонарі [13].

Конститутивним в онкологічній програмі має бути профілактична спрямованість боротьби з раком, що дасть можливість у найближчому майбутньому знизити захворюваність на 50 \%. Важливими на сьогодні є нові направлення в пошуку фінансування онкологічної галузі та iii тарифікації на основі державних нормативів і стандартів онкологічної допомоги, до того ж існують значні недоліки в організації закупівлі за кошти Державного бюджету препаратів для лікування онкологічних хворих і подальшому їх розподілі в мережі онкологічних закладів, відсутність їх автономізації.

Висновки. Розглянувши етапи становлення механізмів державного регулювання трансформації в наданні медичної допомоги хворим зі зло- 
якісними захворюваннями в Україні, в рамках забезпечення хворого зі злоякісними новоутвореннями конституційного права на отримання ефективного лікування, галузь потребує подальшого реформування. Необхідне застосування інноваційних підходів у боротьбі зі злоякісними новоутвореннями, а саме: проведення цілеспрямованої державної політики з формування Національної статегії у боротьбі зі злоякісними новоутвореннями, що спрямована на розвиток багатофункціонального фінансування, підготовки управлінських кадрів, участі України в багатоцентрових клінічних рандомізованих дослідженнях II та III фази за участі пацієнтів зі злоякісними новоутвореннями, залучення інвестицій від міжнародних організацій (приватних та урядових); на регіональному та місцевому рівнях покращення показників діяльності та планування роботи окремих лікувальних онкологічних установ (онкодиспансерів, центрів сучасної онкологічної допомоги), складання локальних формулярів, враховуючи проведення фармакоекономічного аналізу, а також створення відповідної законодавчої бази та програми реалізації національної концепції боротьби зі злоякісними новоутвореннями.

\section{СПИСОК ВИКОРИСТАНИХ ДЖЕРЕЛ}

1. Наказ МОЗ “Про заходи подальшого покращання і розвитку онкологічної допомоги населенню” від 30.12.1992 № 208.

2. Проект наказу МОЗ України "Про удосконалення онкологічної допо- моги населенню України” [Електронний ресурс]. Режим доступу: http://moz.gov.ua

3. Бюлетень Національного канцерреєстру № 16 "Рак в Україні, 20132014” [Електронний ресурс] / Нац. ін-т раку. Київ, 2015. 104 с. Режим доступу: http://www.ncru.inf.ua/ publications/BULL_16/index.htm

4. Загальнодержавна програма боротьби з онкологічними захворюваннями на період до 2016 року (Закон України від 23.12. 2009 р. № 1794/17) [Електронний ресурс]. Режим доступу: http://rada. gov.ua

5. Наказ МОЗ України та НАМН України "Про виконання завдань та заходів Загальнодержавної програми боротьби 3 онкологічними захворюваннями на період до 2016 року” (від 14.05.2010 № 409/36) [Електронний ресурс]. Режим доступу: http://moz.gov.ua

6. Постанова Кабінету Міністрів України про створення програми “Здоров’я нації” на 2002-2011 рр. .від 10.01.2002 р. № 14 .

7. Проект Концепції Державної цільової програми розвитку паліативної та хоспісної допомоги на 2010-2014 роки.

8. Князевич В. М. Паліативна та хоспісна медицина: поняття, компоненти, розвиток в Україні (за науковою літературою) / В. М. Князевич, 3.М.Митник, Ю.І. Губський // Україна. Здоров'я нації. 2009. № 3 (11). C. 55-62.

9. Михайлович Ю. Й. Оцінка якості та ефективності державних програм в онкології / Ю. Й. Михайлович, 3. П. Федоренко, А. В. Журбенко // Думка. Клінічна онкологія. 2014. № 3. С. 9-10.

10. Методологія проведення індивідуальної реабілітації пацієнта 3 інвалідністю внаслідок онкологічного 
захворювання в умовах реабілітаційного центру / С. А. Місяк / / Онкологія. 2015. №17 (4).

11. Потреба в реабілітаційній діяльності для працездатного населення 3 першою групою інвалідності з онкологічними захворюваннями в регіонах України за 2001-2011 рр. / С. А. Місяк // Онкологія. 2016. № 18 (3). С. 233.

12. ХІІІ з”ізд онкологів та радіологів України. Сучасний стан та перспективи галузі. Клінічна онкологія. 2016. № 2(22).

13. Сучасні підходи до організації надання онкологічної допомоги / О. М. Клюсов // Онкологія. 2017. T. 19, № 4. C. 275-281.

\section{REFERENCES}

1. Nakaz MOZ "Pro zakhody podalshoho pokrashchannia i rozvytku onkolohichnoi dopomohy naselenniu" : vid 30.12.1992 \# 208 [Order of the Ministry of Health "On measures to further improve and develop cancer care” from 30.12.1992, № 208]. [in Ukrainian].

2. Pro sy'stemu nadannya onkologichnoyi dopomogy' naselennyu Ukrayiny'.Nakaz Ministerstva oxorogy' zdorov'ya Ukrayiny' \# 845 vid 01.10.2013, Ky'yiv [ Elektronny'j resurs]. - Rezhy'm dostupu: http:// www.moz.gov.ua/ua/portal/ dn 20131001 0845.html

3. Fe $\overline{d o r e n k o, ~ Z . ~ P ., ~ H u l a k, ~ L . ~ O ., ~}$ Mykhailooych, Yu. Y., Horokh, Ye. L., Ryzhov, A. Yu., Sumkina, O. V., et al. (2015). Rak v Ukraini, 2013-2014. Zakhvoriuvanist, smertnist, pokaznyky diialnosti onkolohichnoi sluzhby. Biuleten natsionalnoho kantserreestru ukrainy - Cancer in Ukraine, 2013-2014. Morbidity, mortality, indicators of oncology service activity. Bulletin of the National Can- cer Registry № 16]. Kyiv. Retrieved from http://www.ncru.inf.ua/publications/BULL_16/index.htm [in Ukrainian].

4. Zakon Ukrainy "Pro zatverdzhennia Zahalnoderzhavnoi prohramy borotby z onkolohichnymy zakhvoriuvanniamy na period do 2016 roku" : vid 23 hrudnia 2009 roku № 1794-VI [Law of Ukraine "On approval of the National program of fight against oncological diseases for the period till 2016" from December 23 2009, № 1794-VI]. zakon.rada.gov. ua. Retrieved from https://zakon.rada. gov.ua/laws/show/1794-17\#Text [in Ukrainian].

5. Nakaz MOZ Ukrainy ta NAMN Ukrainy "Pro vykonannia zavdan ta zakhodiv Zahalnoderzhavnoi prohramy borotby $\mathrm{z}$ onkolohichnymy zakhvoriuvanniamy na period do 2016 roku" : vid 14.05.2010 № 409/36 [Order of the Ministry of Health of Ukraine and the National Academy of Medical Sciences of Ukraine "On the implementation of tasks and measures of the National Program for Combating Cancer for the period up to 2016" from 14.05.2010 № 409/36]. ips. ligazakon.net. Retrieved from https:// ips.ligazakon.net/document/view/ moz11323?ed=2010_05_14\&an=96 [in Ukrainian].

6. Postanova Kabinet Ministriv Ukrainy "Pro zatverdzhennia Mizhhaluzevoi kompleksnoi prohramy "Zdorovia natsii" na 2002-2011 roky" : vid 10 sichnia 2002, № 14 [Resolution of the Cabinet of Ministers of Ukraine "On approval of the Intersectoral Comprehensive Program "Health of the Nation" for 2002-2011" from January 10, 2002, № 14]. zakon.rada.gov. ua. Retrieved from https://zakon. rada.gov.ua/laws/show/14-2002$\%$ D0\%BF\#Text [in Ukrainian].

7. Proekt Kontseptsii Derzhavnoi tsilovoi prohramy rozvytku paliatyvnoi ta 
khospisnoi dopomohy na 2010-2014 roky [Draft Concept of the State target program for the development of palliative and hospice care for 2010-2014]. Retrieved from https://www.moz.gov. ua/ua/portal/dn_20080627_0.html. [in Ukrainian].

8. Kniazerych, V. M., Mytnyk, Z. M., Hubskyi, Yu. I. (2009). Paliatyvna ta khospisna medytsyna: poniattia, komponenty, rozvytok v Ukraini (za naukovoiu literaturoiu) [Palliative and hospice medicine: concepts, components, development in Ukraine (according to scientific literature)]. Ukraina. Zdorovia natsii - Ukraine. Health of the nation, 3(11), 55-62 [in Ukrainian].

9. Mykhailovych, Yu. Y. Fedorenko, Z. P., Zhurbenko, A. V. (2014). Otsinka yakosti ta efektyvnosti derzhavnykh prohram $\mathrm{v}$ onkolohii [Evaluation of quality and efficiency of state programs in oncology]. Dumka. Klynichna onkolohiia - Opinion. Clinical oncology, 3, 9-10 [in Ukrainian].

10. Misiak, S. A. (2015). Metodolohiia provedennia indyvidualnoi reabilitatsii patsiienta z invalidnistiu vnaslidok onkolohichnoho zakhvoriuvannia $\mathrm{v}$ umovakh reabilitatsiinoho tsentru [Methodology of individual rehabilitation of a patient with a disability due to cancer in a rehabilitation center]. Onkolohiia - Oncology, 17(4), 292-295 [in Ukrainian].

11. Misiak, S. A. (2016). Potreba v reabilitatsiinii diialnosti dlia pratsezdatnoho naselennia z pershoiu hrupoiu invalidnosti z onkolohichnymy zakhvoriuvanniamy v rehionakh Ukrainy za 2001 - $2011 \mathrm{rr}$. [The need for rehabilitation activities for the working population with the first group of disabilities with cancer in the regions of Ukraine for 2001-2011]. Onkolohiia - Oncology, 18(3), 233 [in Ukrainian].

12. Sniehiroz, P. (2016). XIII Zyizd onkolohiv ta radiolohiv Ukrainy. Suchasnyi stan ta perspektyvy haluzi [13th Congress of Oncologists and Radiologists of Ukraine. Current state and prospects of the industry]. Klinichna onkolohiia - Clinical Oncology, 2(22). Retrieved from https:// www.clinicaloncology.com.ua/article/16472/xiii-z-izd-onkologiv-taradiologiv-ukraini-suchasnij-stan-iperspektivi-galuzi [in Ukrainian].

13. Kliusov, O. M. (2017). Suchasni pidkhody do orhanizatsii nadannia onkolohichnoi dopomohy [Modern approaches to the organization of oncological care]. Onkolohiia - Oncology, 19(4), 275-281 [in Ukrainian]. 